\title{
Justiça Transicional na África do Sul: Restaurando o Passado, Construindo (1) Futuro*
}

\author{
Simone Martins Rodrigues Pinto**
}

\section{Introdução}

A transição na África do Sul, de um longo regime de opressão segregacionista para uma democracia multirracial, deu-se de forma surpreendentemente pacífica e negociada. Graças ao exemplo de Nelson Mandela, que foi solto depois de 27 anos de prisão, e à condução moral do arcebispo Desmond Tutu, como baluarte de uma nova forma de justiça, o país não se desintegrou em novas disputas de poder.

Apesar de negociada, a transição não resultou em uma anistia geral que levasse ao esquecimento do passado. A principal novidade no

\footnotetext{
*Artigo recebido em agosto de 2006 e aprovado para publicação em maio de 2007.

***Doutora pelo Instituto Universitário de Pesquisas do Rio de Janeiro da Universidade Candido Mendes (Iuperj/Ucam) e professora do Centro de Pesquisa e Pós-graduação sobre as Américas da Universidade de Brasília (Ceppac/UnB).
}

CONTEXTO INTERNACIONAL Rio de Janeiro, vol. 29, n 2, julho/dezembro 2007, p. 393-421. 
processo sul-africano foi a ênfase na verdade e na responsabilização. Em busca da restauração social da sociedade, a punição ficou em segundo plano, dando lugar a uma outra forma de resposta coletiva aos abusos perpetrados por meio de uma justiça restaurativa.

\section{O Regime de Apartheid}

A política de apartheid, ou segregação, foi institucionalizada na África do Sul em 1948 e legitimou um sistema totalitário de discriminação racial, espacial, jurídico, político, econômico, social e cultural. No entanto, a África do Sul tem experimentado racismo e opressão desde a chegada dos primeiros colonizadores. O país está localizado ao sul do continente africano, banhado pelos oceanos Atlântico e Índico, tornando-se um ponto estratégico das rotas comerciais européias para o Oriente. Os europeus chegaram ao país em 1487, quando o navegador português Bartolomeu Dias contornou o Cabo da Boa Esperança em busca das rotas comerciais para as Índias. Habitada inicialmente por diversos grupos negros, como os boxímanes, khoikhois, xhosas, sans e zulus, a região foi colonizada por imigrantes holandeses, ${ }^{1}$ franceses e alemães no século XVII.

Apesar de a institucionalização do apartheid se dar somente em 1948, a história da colonização da África do Sul é marcada pela separação étnica e pela escravidão. $O$ país foi colonizado primeiro pelos holandeses e depois pelos britânicos. Quando da chegada dos holandeses, o povo khoikhois, essencialmente formado por pastores de gado, e o povo sans, caçadores e coletores, habitavam a terra que hoje constitui o país. Outros povos agricultores, como os xhosas, zulus, suazis e ndebeles, tswanas e basothos, habitavam o interior do território (JONGE, 1991, p. 16).

A colonização holandesa começou com a chegada da Companhia das Índias Orientais, que a princípio intencionava apenas estabelecer um entreposto de abastecimento dos navios em trânsito para a Ásia. Em 
poucos anos, os holandeses começaram a se estabelecer na Cidade do Cabo, tornando-se os novos colonos, juntamente com alguns alemães e franceses vindos da Europa. A expansão da colonização deu-se por meio de numerosas guerras contra os khoikhois, que foram dizimados pela varíola, mortos pelos colonos ou escravizados. Ainda no século XIX, a Companhia das Índias proibiu a escravização dos khoikhois e eles foram integrados na sociedade por meio de um sistema de clientela que não era muito melhor do que o de escravidão. Apesar de livres, eles ocupavam uma posição muito inferior na sociedade. Jan van Riebeeck, o primeiro governador da Colônia do Cabo referiu-se a eles como "gente estúpida e malcheirosa" (JONGE, 1991, p. 10). Com relação ao povo san, os colonos holandeses adotaram uma clara política de genocídio. Em 1798, a Colônia do Cabo tinha 26 mil escravos, 15 mil khoikhois e 22 mil africânderes. O pequeno número de mulheres brancas facilitou uma ampla miscigenação, fazendo surgir os mestiços.

Com o fortalecimento do poder da Inglaterra na Europa, o império colonial holandês perdeu força e os ingleses passaram a dominar o Cabo. A administração britânica era mais liberal. Em 1828, decretou direitos iguais entre os habitantes da colônia e, mais tarde, aboliu a escravidão. Para os africânderes, a libertação dos escravos constituiu uma abominação. Uma forte ideologia, baseada em distorções da Bíblia, mantinha os africânderes contrários à igualdade com os negros. Estas medidas, aliadas à escassez de terras, levaram a população africânder a migrar para o interior, onde fundaram duas repúblicas independentes, o Transvaal e o Estado Livre de Orange. Estas repúblicas praticavam uma política racial rígida e os não-brancos eram considerados estrangeiros e tolerados somente como força de trabalho subordinada (BOBBIO; MATTEUCCI; PASQUINO, 1985, p. 55). Da mesma forma que acontece hoje, o fim legal do apartheid não elimina de imediato o fim do apartheid social. Uma sociedade construída sobre a visão da separação, da superioridade racial e da intolerância 


\section{Simone Martins Rodrigues Pinto}

resiste em aceitar uma igualdade firmada por lei. Por isto, a transição precisa ser feita levando em consideração a necessidade de derrubar estas fortes barreiras sociais e culturais, buscando afetar e alterar a cosmovisão de toda uma nação.

A tentativa de anexação da República do Transvaal pelos ingleses deu início a um nacionalismo africânder, que se reforçava na idéia de que os colonos holandeses eram uma nação única, falante de uma língua dada por Deus e perseguida por um inimigo pérfido. Preocupados com a diversidade de unidades políticas, os ingleses iniciaram guerras sangrentas contra a resistência zulu e as repúblicas bôeres.

Para consolidar a dominação inglesa, Alfred Milner, alto comissário britânico da África do Sul desde 1897, provocou a Segunda Guerra Anglo-Bôer, derrotando os africânderes e dominando Orange e o Transvaal. ${ }^{2}$ A fim de atender à necessidade de força de trabalho, Milner, sustentado pela ideologia do darwinismo social, intensificou as práticas relativas às reservas tribais, mais tarde chamadas de bantustões, e às leis do passe. $\mathrm{O}$ apartheid, após se consolidar como política, também reformulou sua ideologia. Esta, antes baseada na idéia da desigualdade, quando se tornou um projeto político passou a ser identificada como desenvolvimento separado. Os bantustões passaram a se chamar homelands e tornaram-se o ícone da separação racial (BOBBIO; MATTEUCCI; PASQUINO, 1985, p. 55).

Para garantir a mão-de-obra negra, muitas medidas foram adotadas ainda no século XIX. Além da apropriação das terras dos povos nativos, foram instituídos impostos altos que obrigavam os negros a procurarem fontes de renda para pagá-los. Também as leis do passe compeliram os negros a conseguirem emprego em no máximo seis dias a partir de sua chegada em uma área de trabalho, sob pena de multa, prisão ou expulsão, caso o prazo não fosse cumprido. Os negros eram apenas permitidos fora das reservas tribais se fossem considerados força de trabalho essencial à economia branca. As idéias 
evolucionistas que encheram a Europa neste período ganharam significado especial no regime sul-africano. Os negros foram considerados uma raça forte, boa para trabalhos braçais e não apta à educação mais refinada. Respaldados nesta doutrina considerada "científica", muitos empregadores puderam ter suas consciências aplacadas, caso houvesse algum lampejo de dúvida a respeito do regime de apartheid.

A Lei da Terra, de 1913, impedia que negros possuíssem mais de $13 \%$ da área total do país, porcentagem referente aos bantustões. Rapidamente, estas áreas ficaram superlotadas, impedindo a agricultura e o pastoreio. Assim, os negros viram-se obrigados a vender sua força de trabalho aos brancos. Mesmo em áreas urbanas, a permanência de negros era restrita.

Como reação a este processo de proletarização e segregação dos negros, foi fundado o Congresso Nacional Africano (CNA), em 1912. Em 1914, o ex-general bôer, Barry Hertzog, fundou o Partido Nacional (PN), que proclamava um racismo radical. Em 1918, foi fundada a Liga Africânder dos Irmãos, uma organização semi-religiosa que mais tarde se tornou secreta (JONGE, 1991, p. 42). A Liga penetrou rapidamente em todas as esferas da sociedade, em associações culturais, igrejas, sindicatos e partidos. Seu papel foi fundamental na construção de um pensamento conservador e na reafirmação da obsessão por uma pureza racial.

A política de segregação racial do apartheid foi oficializada em 1948, com a chegada ao poder do Partido Nacional, que dominou a política por mais de quarenta anos. O apartheid impediu o acesso dos negros à propriedade da terra e à participação política e obrigou-os a viver em zonas residenciais segregadas. A Lei de Registro Populacional, de 1950, garantiu uma rígida hierarquização racial, outorgando direitos políticos, econômicos e sociais desiguais para cada uma das categorias raciais. A lei institucionalizou quatro categorias raciais - 
branco, mestiço, asiático e negro. A forma de classificação era arbitrária e baseada em critérios de aparência. Ser classificado como negro trazia conseqüências graves. A Lei das Áreas de Grupo, também de 1950, estabeleceu a separação espacial das categorias raciais, obrigando as pessoas a fixarem suas residências em áreas determinadas. A Lei da Conservação de Diversões Separadas instituiu o uso separado de praias, transportes, piscinas, bibliotecas, banheiros públicos, teatros, cinemas e praças. A segregação das áreas residenciais e locais e serviços públicos gerou a criação dos passes e dos assentamentos negros, chamados bantustões. Outras leis garantiam a posse da terra para os brancos, a proibição de casamentos mistos, a regulamentação da educação banto, a censura etc.

Havia muitas leis de controle ideológico, como o estabelecimento de punição para o jornal que publicasse qualquer artigo que "prejudicasse" as relações entre brancos e negros ou que afirmasse que o regime de apartheid era injusto. Da mesma forma, o branco que declarasse que as leis do apartheid eram injustas poderia ser condenado à prisão e ao pagamento de multas.

Na década de 1950, em reação a este conjunto de leis separatistas, a oposição ao apartheid tomou forma e o Congresso Nacional Africano lançou uma campanha de desobediência civil, que foi respondida com mais violência. ${ }^{3}$ Em 1960, o CNA organizou uma campanha antipasses - o negro que era pego sem o seu passe, um livrinho de quase cem páginas, era preso e punido. Em 21 de março, uma multidão de voluntários foi arregimentada para se apresentar sem seus passes em frente à delegacia de polícia de Shaperville, em uma demonstração pacífica de resistência. A manifestação foi reprimida com extrema violência, gerando 67 mortos. Como forma de repressão, o CNA foi declarado ilegal e seu líder, Nelson Mandela, foi preso e condenado à prisão perpétua em 1962. O Massacre de Shaperville, como ficou conhecido, provocou protestos no país e no exterior. 
Em 1969, surgiu o Movimento da Consciência Negra, liderado por Steve Biko. Biko, influenciado por Frantz Fanon, lutava pela libertação psicológica do povo e contra a educação inferior e destrutiva dos valores dos povos negros. Quando o ministro-adjunto da Educação banta, Andries Treurnicht, um africânder conservador, quis introduzir a língua africânder nas escolas negras, alunos da cidade negra de Soweto, próxima a Joanesburgo, iniciaram uma greve, inspirados pelas idéias da Consciência Negra. Durante uma demonstração pacífica em 1976, muitas crianças foram mortas. As manifestações eclodiram em outras cidades e, no fim de dezesseis meses, já havia seiscentos mortos. Esses massacres chamaram a atenção internacional e fortaleceram o CNA, que operava no exílio.

Os governos dos primeiros-ministros Hendrik Verwoerd (1958-1966) e B. J. Vorster (1966-1978) recrudesceram a política de apartheid. Uma série de leis foram promulgadas para classificar e separar os negros em grupos étnicos, na tentativa de confiná-los em territórios tribais, denominados bantustões. Em 1976, P. W. Botha assumiu como primeiro-ministro, acirrando a luta contra a oposição. Ao mesmo tempo que crescia a repressão, Botha começava pequenas reformas para conquistar uma classe média negra. Em 1983, ele apresentou uma nova Constituição, referendada por $66 \%$ dos brancos, que previa alguma participação de outros grupos raciais que não os brancos na política. Mas a conjugação de reforma e repressão não funcionou para aplacar as reivindicações por democracia. Se, por um lado, as reformas mostravam disposição de abertura política, a repressão aumentava a opressão sobre os grupos negros.

Com o fim do império colonial português na África (1975) e a queda do governo de minoria branca na Rodésia, atual Zimbábue, o domínio branco na África do Sul entrou em crise. A militância negra cresceu cada vez mais e os problemas econômicos agravaram a situação. A queda do preço do ouro, principal produto de exportação, o custo das incursões na Namíbia e Angola, o custo do sistema de repressão 


\section{Simone Martins Rodrigues Pinto}

interno e, principalmente, a reação estrangeira são fatores que contribuíram para a crise do regime.

Os bancos internacionais, pressionados pela sociedade civil estrangeira e por razões econômicas e políticas, cancelaram os créditos à África do Sul e exigiram o pagamento de seus débitos a curto prazo. A moeda caiu e houve fuga de capitais, espantando grandes empresas - como a General Motors, a Kodak, a IBM, a Ford e a Coca-Cola - do país. Em 1984, uma revolta popular contra o apartheid levou o governo a decretar lei marcial, restringindo ainda mais os parcos direitos dos negros. A Organização das Nações Unidas (ONU) reagiu impondo sanções à África do Sul como forma de pressão. Acuado, Pieter Botha promoveu reformas, mas manteve os aspectos essenciais do regime racista. Paralelamente, no mundo todo crescia o movimento pela libertação de Mandela.

Em 1989, Botha sofreu um ataque cardíaco e abdicou da função de líder do Partido Nacional. Frederik W. De Klerk chegou à Presidência por meio de eleições em setembro de 1989. No dia 2 de fevereiro de 1990, De Klerk anunciou a legalização do CNA, do Partido Comunista, do Congresso Pan-Africano e de outros grupos de oposição, além da libertação de alguns presos políticos, dentre eles Mandela. A decisão também incluía uma moratória nas execuções de pena de morte e a revogação da censura da imprensa. Externamente, o clima de pós-Guerra Fria predominava. Com a nova configuração do sistema internacional, a África do Sul tornou-se um problema periférico, que não despertava o interesse nem da Rússia, que buscava se reestruturar, nem dos EUA, que já não sentiam a ameaça comunista no continente africano. Sem o apoio dos EUA, o regime conservador sul-africano não duraria muito.

Internamente, o Partido Conservador de Andries Treurnicht e a organização paramilitar e fascista de Eugene Terreblance - o Movimento de Resistência Africânder - logo se mostraram insatisfeitos com as 
reformas e, por meio de ameaças de violência, prometiam proteger os interesses da minoria branca. Pressionado pelas condições políticas internas e externas e pela economia, De Klerk começou a negociar a transição política.

Em 1990, Mandela foi libertado e o CNA recuperou a legalidade. As leis raciais foram revogadas e um plebiscito só para brancos, realizado em 1992, apontou que $69 \%$ dos votantes eram a favor do fim do regime de apartheid. Assim, em 1994, foram convocadas as primeiras eleições multirraciais para um governo de transição, nas quais venceu Nelson Mandela.

A África do Sul elaborou sua Constituição de transição sem a mediação de forças externas, enfatizando a noção de contrato entre todas as partes envolvidas. A nova Constituição, de 1996, tentou equilibrar o poder de brancos e negros, procurando manter o espírito de compromisso entre as facções. O novo Estado operou largamente por meio da velha burocracia do apartheid, evitando qualquer ruptura mais brusca. Em muitos casos, isto causou ações de obstrução e manutenção do status quo, mas garantiu uma transição mais tranqüila.

Outro grande desafio era que a maioria das províncias estava dividida em linhas étnicas. O Nordeste do país é predominantemente tswana, a província de Free State é sotho, KwaZulu-Natal é zulu, Cabo Oriental é xhosa, Cabo Setentrional e Cabo Ocidental são predominantemente habitadas por povos africânderes (SELETI, 1998, p. 88). No entanto, a maioria dos partidos da transição, como o Congresso Nacional Africano e o Congresso Pan-Africano, não usaram as identidades étnicas em suas agendas políticas, evitando possíveis manipulações de ideologias nacionalistas e sectárias. Muitos apostaram que a África pós-apartheid iria se diluir em guerra étnica, mas isto não ocorreu.

A transição deu lugar à construção de uma nova história. A celebração de heróis e heroínas africanas passou a fazer parte do discurso 


\section{Simone Martins Rodrigues Pinto}

político. Por meio de seus intelectuais, o CNA iniciou um processo de reinterpretação do passado para justificar o compromisso com a revolução democrática. O então presidente do CNA, Thabo Mbeki, ${ }^{4}$ discursando no estádio de Mafeking em dezembro de 1997, relembrou a resistência da província à ocupação colonial e depois a exaltou como baluarte da luta contra o apartheid. O simbolismo destas lembranças ajudou a refazer a identidade da África do Sul. A celebração do Dia de Shaka, um chefe zulu reconhecido pela luta contra o colonialismo, fez parte da tentativa de forjar um novo patriotismo. Em 1997, foi construída a estátua em memória de Steve Bantuboke Biko, o líder negro morto pela polícia no período do apartheid. A busca da Cabeça de Hintsa, um guerreiro e chefe xhosa que foi morto pelos britânicos no século XIX e que, segundo a lenda, teve sua cabeça levada para a Escócia, fez parte da busca de novos símbolos nacionais. O grande interesse da mídia e da comunidade científica em investigar se a cabeça encontrada na Escócia era mesmo do chefe xhosa produziu um novo movimento de recuperação da história de resistência (SELETI, 1998, p. 93).

Apesar da recuperação da cultura negra, o CNA preocupou-se em criar uma identidade nacional de um país unitário, não racista, multicultural e democrático. $\mathrm{O}$ arco-íris foi a marca e o símbolo deste novo Estado. Na busca de uma nova identidade sul-africana e a fim de evitar as divisões maléficas existentes no país, Mbeki (apud SELETI, 1998, p. 95, tradução minha) declarou na ocasião da adoção da nova Constituição em maio de 1997:

Nós estamos reunidos aqui hoje para comemorar a vitória na aquisição e exercício do direito de formular nossa própria definição do que significa ser sul-africano. A Constituição cuja adoção nós celebramos constitui uma declaração inequívoca de que nós nos recusamos a aceitar que nossa africanidade deve ser definida pela nossa raça, cor, gênero ou origem histórica 


\section{Justiça Transicional na África do Sul:}

Restaurando o Passado...

[...]. Ela expressa concretamente o sentimento que compartilhamos como africanos [...] que o povo deve governar. ${ }^{5}$

Alguns partidos, como o ultradireitista Movimento de Resistência Africânder, liderado por Eugene Terreblanche, ainda continuaram suas tentativas de proteger as minorias, mas em geral o país embarcou na idéia da unidade.

\section{A Comissão de Verdade e Reconciliação}

Não havia dúvidas quanto à necessidade de um novo começo para a África do Sul; a questão seria como o processo transicional se desenvolveria. Duas conferências foram organizadas em 1994 na Cidade do Cabo para discutir como lidar com o passado. A primeira conferência, em fevereiro, teve suas discussões publicadas no dossiê Dealing with the past: truth and reconciliation in South Africa. Representantes do leste europeu e da América Latina compartilharam suas experiências durante a conferência, mostrando diversos modelos de justiça transicional. A segunda conferência ocorreu em julho, focando principalmente as organizações sul-africanas. Muitas organizações sul-africanas, dos dois lados do problema, opuseram-se à criação de uma comissão de verdade e não enviaram delegados. O resultado da conferência foi publicado no dossiê The healing of a nation.

A idéia da comissão de verdade começou, ironicamente, com as acusações de abusos aos direitos humanos cometidos pelo Congresso Nacional Africano em alguns campos no exílio. A resposta do Congresso foi instaurar uma comissão de inquérito. Em março de 1992, o presidente Nelson Mandela criou a Comissão de Inquérito sobre as Reclamações feitas por Antigos Prisioneiros e Detidos pelo Congresso Nacional Africano. A Comissão estava focada principalmente nos eventos ocorridos nos campos de detenção localizados no su- 
deste da África, como Angola, Tanzânia e Zâmbia. O Congresso Nacional Africano representa o único caso de entidade não-governamental - configurada como um movimento de oposição e de resistência armada - que estabeleceu uma comissão para investigar e publicar o relatório dos seus próprios abusos aos direitos humanos. Sete meses depois, a Comissão submeteu à Presidência um relatório de 74 páginas detalhando as atrocidades cometidas nos campos de detenção. O relatório foi publicado, atraindo a atenção internacional e forçando o Congresso Nacional Africano a responder publicamente às acusações, mas nenhum indivíduo foi pessoalmente acusado. O relatório final foi muito criticado por falta de imparcialidade, decorrente da participação de alguns membros do CNA entre os comissionados. ${ }^{6}$ Assim, uma segunda comissão foi instaurada.

Logo depois de terminado o trabalho desta Comissão em 1992, Nelson Mandela nomeou uma nova comissão de inquérito, também para investigar abusos do Congresso Nacional Africano e responder às críticas referentes à parcialidade das conclusões. A nova comissão foi liderada por três pessoas, um representante da África do Sul, um dos EUA e um do Zimbábue. O trabalho da segunda Comissão foi realizado de maneira mais formal, com a nomeação de um grupo de defensores para representar os acusados, podendo as vítimas também serem representadas por advogados. O relatório chegou às mesmas conclusões do primeiro, mas citando o nome de indivíduos específicos, acusados de violação aos direitos humanos. O CNA respondeu com um longo discurso aceitando as conclusões gerais e reivindicando que uma nova comissão de verdade fosse criada para investigar os abusos cometidos por ambos os lados desde 1948 (HAYNER, 2002, p. 60).

Depois de dezoito meses de intenso debate e preparação, o parlamento sul-africano aprovou o Ato de Promoção da Unidade e Reconciliação Nacional, em 1995, que estabelecia a Comissão de Verdade e Reconciliação. A Comissão foi chefiada pelo arcebispo Desmond Tutu. 
As audiências começaram em 1996, e o relatório de cinco volumes foi publicado em outubro de 1998. Foram ouvidos testemunhos de mais de 23 mil vítimas e testemunhas, sendo mais de duas mil em audiências públicas (VILLA-VICENCIO; VERWOERD, 2000, p. 284).

Em 1995, quando a África do Sul pós-apartheid estabeleceu a Comissão de Verdade e Reconciliação, recebeu duras críticas dos ativistas ocidentais por oferecer anistia aos agentes da opressão. Todavia, os procedimentos foram baseados na idéia de justiça restaurativa e não retributiva. Apesar da anistia, o reconhecimento da verdade e a rejeição social dos atos cometidos funcionaram como um processo de reprovação moral. O arcebispo anglicano Desmond Tutu, um dos maiores defensores das comissões de verdade e da justiça restaurativa, ressaltou que esta visão é baseada não só em idéias cristãs de perdão para aqueles que reconhecem seus erros como também no conceito indígena africano de ubuntu.

A definição de ubuntu, desenvolvida por Tutu, está ligada à busca por harmonia social. Em suas palavras, "um ser humano só é um ser humano por meio de outros e, se um deles é humilhado ou diminuído, o outro o será igualmente" (TUTU, 2000, p. 35, tradução minha). É a idéia de compartilhamento, de pertencimento a uma comunidade.

Para ele, uma justiça nos moldes de Nuremberg não seria possível na África do Sul, porque poria em risco a transição pacífica e negociada. Nenhum lado poderia impor uma justiça dos vencedores, pois nenhum lado teve uma vitória definitiva: "Enquanto os Aliados podiam fazer as malas e voltar para casa depois de Nuremberg, nós na África do Sul temos que conviver uns com os outros" (TUTU, 2000, p. 21, tradução minha).

Outro problema levantado pelo bispo é o custo dos julgamentos. Um país que precisa investir em educação, alimentação, moradia e saúde não poderia arcar com os custos dos julgamentos formais. Só o julga- 
mento do ex-ministro da Defesa, general Magnus Malan, custou cerca de 2 milhões de dólares (TUTU, 2000, p. 23).

O conceito de justiça, neste caso, visa mais o aspecto restaurador do que o punitivo. De acordo com Tutu (apud MINOW, 1998, p. 81, tradução minha),

[...] justiça retributiva é largamente ocidental. O entendimento africano é muito mais restaurativo - não tanto para punir como para compensar e restaurar o equilíbrio que foi quebrado. A justiça que esperamos é restauradora da dignidade das pessoas.

Justiça, neste aspecto, torna-se um conceito mais amplo e ambicioso, que estrapola o caráter da coerção e retribuição para atingir os níveis de dignidade moral e social. A sociedade torna-se parte fundamental no processo, que inclui a vítima como protagonista. $\mathrm{O}$ acusado é responsabilizado, mas sua punição tem caráter moral, fazendo com que reflita sobre sua participação no apartheid e sobre as consequiências de seus atos. Nem todos se arrependem, mas a confrontação com a vítima e com a conscientização dos danos que causou evita que posturas de negação se sustentem.

Na África do Sul, o Ato de Promoção da Unidade e Reconciliação Nacional, promulgado para cobrir o período de 1o de março de 1960, o mês do Massacre de Shaperville, até 5 de dezembro de 1993, estabeleceu como meta produzir a unidade e a reconciliação promovendo a investigação e o total esclarecimento das maciças violações aos direitos humanos cometidas no passado. Ele estava baseado no princípio de que reconciliação depende de perdão e que este pode ser alcançado somente se as violações aos direitos humanos forem esclarecidas. A revelação da verdade surge como o fundamento para a reconciliação. 


\section{Justiça Transicional na África do Sul:}

Restaurando o Passado...

Quanto à abrangência temporal da jurisdição da Comissão de Verdade, as posições foram divergentes. A África do Sul tem experimentado racismo e opressão desde a chegada dos primeiros colonizadores. Muitos, portanto, alegaram que a jurisdição temporal da Comissão de Verdade deveria começar em 1652. Outros consideraram que a data de início deveria ser 1910, quando a primeira Constituição, já repleta de discriminação e de valorização da hegemonia branca, foi promulgada. Ainda houve quem considerasse o melhor termo o ano de 1948, quando o Partido Nacional subiu ao poder. Mas, depois de cuidadosa análise, o Comitê de Justiça do Parlamento decidiu por março de 1960, coincidindo com o banimento das organizações políticas, o recrudescimento da opressão contra a resistência ao apartheid e o massacre de Shaperville (BORAINE, 2000, p. 141).

Em 20 de outubro de 1998, a Comissão de Verdade publicou seu relatório final, sob as críticas principalmente da elite branca e do Partido da Liberdade Inkatha, de defesa radical dos interesses zulu. A principal crítica foi a de que o relatório foi fruto de uma caça às bruxas. Por outro lado, algumas vítimas se mostraram insatisfeitas com a falta de punição.

A Comissão procurou a diversidade de seus componentes. Em sua primeira reunião, havia dez negros e seis brancos, incluindo dois africânderes. Politicamente, a Comissão englobava desde a direita conservadora até a esquerda libertária, além de cristãos, muçulmanos, hindus e agnósticos (TUTU, 2000, p. 74). O Ato instituía dezessete comissionados, trabalhando em tempo integral, e criava três diferentes comitês: o Comitê de Direitos Humanos, que conduzia as audiências públicas das vítimas e sobreviventes; o Comitê de Reparação e Reabilitação, que tratava da política de reparação e assistência; e o Comitê de Anistia, que ouvia e avaliava os pedidos de anistia (BORAINE, 2000, p. 145-146).

A Comissão decidiu regionalizar as audiências, operando em Durban, East London, Johannesburg e Cidade do Cabo. A primeira au- 
diência foi escolhida estrategicamente em Cabo Oriental, onde nasceram os principais membros da resistência, como Mandela, Biko, Thabo Mbeki entre outros. Também foi onde ocorreram os principais enfrentamentos entre os nativos e a ocupação branca.

Os objetivos da Comissão estavam centrados na unidade nacional e na reconciliação como oposição ao conflito e às divisões do passado. Porém, os termos "unidade nacional" e "reconciliação" não foram definidos no Ato. Pode-se, entretanto, extrair, com base no seu Relatório Final, dos três principais objetivos da Comissão, o que se quer buscar a fim de promover a reconciliação:

\section{A) Verdade}

Estabelecer um completo cenário das causas, natureza e extensão das violações aos direitos humanos que foram cometidas durante o período discriminado, incluindo antecedentes, circunstâncias, fatores e contexto das violações, além das perspectivas das vítimas e os motivos e percepções das pessoas consideradas responsáveis, conduzindo, para isto, investigações e oitivas. As idéias prevalecentes são a de que a memória constitui a identidade de uma sociedade e de que a África do Sul precisa de uma nova identidade, baseada em uma nova ordem moral. Assim, ninguém de boa fé poderá negar o passado, distorcendo os fatos a favor dos interesses de alguns grupos.

É comum que governos neguem a ocorrência de violação e criem mitos a respeito dos fatos. Os sérvios negaram a ocorrência de massacres na Bósnia até que covas coletivas foram desvendadas. Da mesma forma, o governo sul-africano construiu, com a ajuda da mídia, o mito do negro selvagem e perigoso, que estava sendo disciplinado para se desenvolver, mas nunca oprimido. A África do Sul viveu um longo período em que a mentira e a dissimulação eram a base da política governamental. O rádio, a televisão e o sistema educacional eram veículos de reforço do regime opressivo. Desde pequenas, as 


\section{Justiça Transicional na África do Sul:}

Restaurando o Passado...

crianças eram educadas e moldadas para viverem neste sistema de preconceito e separação.

Analisando o Relatório Final, percebe-se que a Comissão de Verdade distinguiu entre quatro tipos de verdade: a primeira é a verdade factual, que buscava um amplo relato que compreendia as atividades e as descobertas baseadas em informações factuais e evidências coletadas ou recebidas pela Comissão ou colocadas à sua disposição por órgãos governamentais ou organizações privadas. A segunda é a verdade pessoal, baseada na história individual contada pelas vítimas e pelos perpetradores, dando significado a suas experiências pessoais e, assim, permitindo a restauração da dignidade humana e civil das vítimas, dando a elas a oportunidade de relatar sua versão das violações que sofreram. A terceira é a verdade social ou dialógica, ou seja, a verdade instituída por meio da interação, da discussão e do debate. E, finalmente, a quarta é a verdade restaurativa ou curativa, que requer o reconhecimento e a reprovação moral do passado e a construção de uma nova memória coletiva.

Tutu (2000, p. 30) cita a peça do dramaturgo chileno, Ariel Dorfman, "A morte e a donzela", para exemplificar o poder curativo do reconhecimento da verdade. A peça conta que, enquanto a mulher estava ocupada na cozinha, um homem, cujo carro quebrara em frente à sua casa, estava conversando com seu marido. A mulher não o viu, mas identificou sua voz como a daquele que a havia torturado e estuprado na prisão. Ela então pega uma arma e aponta para ele e está pronta a matar enquanto ele nega o fato e elabora um álibi. Quando ele finalmente assume que a torturou, ela larga a arma e o deixa ir. Assim, fica clara a idéia de que o reconhecimento do crime é peça fundamental para o perdão.

A viúva de Mapetla Mohapi, líder do Movimento da Consciência Negra, que foi encontrado em sua cela enforcado e com um bilhete de suicídio, sempre acreditou que ele tivesse sido assassinado. No en- 
tanto, nenhum processo legal para saber a verdade ou uma ação civil levou a algum resultado. Pelo contrário, ela foi multada várias vezes em somas altas por estar "criando problemas". A única coisa que ela queria era saber a verdade sobre a morte de seu marido. Dezenove anos depois, ela foi ouvida pela Comissão de Verdade e testemunhou que o ambiente amigável da Comissão e o interesse em saber de sua história a fez sentir-se honrada e com a sua dignidade restaurada (BORAINE, 2000, p. 160).

Sem a Comissão de Verdade, a revelação dos fatos ficaria bem limitada. Mesmo julgamentos criminais dão uma parcela muito restrita dos acontecimentos, apenas o suficiente para estabelecer a responsabilidade do acusado. O reconhecimento, como veículo de transformação de uma sociedade, vai além da descoberta de quem matou; ela surge para alterar valores e reconstruir o passado em novas bases.

\section{B) Perdão e anistia}

O objetivo mais controverso do Ato de instituição da Comissão de Verdade é, sem dúvida, o de facilitar a anistia das pessoas que esclarecerem completamente os fatos relevantes relacionados aos atos associados com objetivos políticos. Mas sua ênfase é clara no reconhecimento e na verdade, mais do que na punição. É psicologicamente vital para as famílias das vítimas saberem o que ocorreu, e esse esclarecimento é também necessário para que haja reparação e compensação adequadas. Por isso, a anistia surge como instrumento de obtenção da verdade.

Para obter a anistia, o violador não precisa mostrar remorso, basta convencer a Comissão de que os atos cometidos tiveram objetivos políticos e que foram amplamente esclarecidos. Este processo é baseado na reciprocidade - sobreviventes podem contar suas histórias publicamente, ter o reconhecimento oficial e receber reparações. Por outro lado, os agentes também podem construir sua narrativa dos fa- 
tos e receber a anistia. No processo de anistia da África do Sul, o violador tem de se identificar como culpado e descrever minimamente os atos pelos quais acredita que precisa de anistia. Aqueles que requerem anistia por violações mais graves devem participar das audiências públicas e ser questionados pela Comissão e, em alguns casos, pelas vítimas e famílias das vítimas. O requerente tem de assumir a responsabilidade pelos seus atos de maneira específica e individual, ao contrário dos processos de anistia geral. Os anistiados são identificados e impedidos de ocupar posições que lhes permitam repetir a violência.

A Comissão concedeu a anistia para mais de mil, dentre cerca de 7 mil requerentes, e, apesar das críticas vindas de organizações internacionais, dos partidos políticos e das vítimas, o governo acredita que a anistia foi a única transição possível, entre a anistia geral sem responsabilização e os julgamentos criminais (HAYNER, 2002, p. 44). O Comitê de Anistia recebe os pedidos e tem a prerrogativa de negá-los. Da mesma forma, pode fazer recomendações às autoridades judiciais apropriadas para que haja julgamento judicial.

Nesta balança, em que as vítimas recebem compensação e desistem da vingança e os perpetradores confessam a culpa e são anistiados, fica reforçado o caráter restaurativo da justiça. Os indivíduos desistem do seu direito de retribuição em favor da estabilidade e paz futura. Mas não sem antes ter o devido acesso à verdade e à reprovação moral.

O perdão é um passo fundamental para a real reconciliação. Segundo Hannah Arendt (1997), o perdão não está limitado à vida privada, mas pode estar ligado à vida pública. O perdão na vida pública tem se mostrado uma experiência política complexa, mas autêntica:

[...] a única solução possível para o problema da irreversibilidade - a impossibilidade de se desfazer o que se fez, embora não se soubesse nem 


\section{Simone Martins Rodrigues Pinto}

se pudesse saber o que se fazia - é a faculdade de perdoar. A solução para o problema da imprevisibilidade, da caótica incerteza do futuro, está contida na faculdade de prometer e cumprir promessas. (Arendt, 1997, p. 248).

Embora a lei de anistia não requeira a demonstração de remorso ou arrependimento, a divulgação pública torna-se uma forma de exposição e humilhação. Muitos membros das forças de segurança que pleitearam anistia eram pessoas respeitáveis em sua comunidade e muitas vezes nem sua família tinha idéia das atrocidades que cometera. A punição nestes casos é de caráter moral, configurando a perda da honra pessoal. A comunidade, assim, participa da decisão de aceitação ou rejeição do perpetrador no seu seio novamente.

Desmond Tutu (2000) nega que a anistia encoraje a impunidade porque a anistia na África do Sul só é dada a quem reconhece sua responsabilidade e afirma ser culpado. A justiça, neste caso, seria falha somente tomando-se em conta o conceito de justiça retributiva, mas não de justiça restaurativa. No espírito do ubuntu, a restauração das relações quebradas, a reabilitação da vítima e do violador e a cura das feridas são as metas mais importantes.

Embora Tutu procure associar a justiça restaurativa e o perdão à tradição africana, seu fundamento está bastante ligado à idéia de graça cristã. A graça, referida como favor imerecido, é o que fundamenta a necessidade de perdão por parte dos cristãos. Da mesma forma, o perdão também é associado ao processo de restauração do transgressor. A obra de Victor Hugo Os miseráveis ilustra como o perdão pode restaurar um espírito duro e amargurado, pronto para a transgressão social. ${ }^{7}$

Sem esse processo de troca - "anistia pela verdade" - não teria sido possível desvendar tantos casos de morte, tortura e seqüestros. Esse processo não tem paralelos em nenhuma outra transição, constituindo uma característica única da África do Sul. O ato criminoso é re- 
provado legalmente e em público, o relatório é publicado e os culpados são declarados, mas a punição tem um caráter social e moral.

\section{C) Reconhecimento e restauração}

Uma das principais metas expressas no Ato é restaurar a dignidade humana e civil das vítimas, dando-lhes a oportunidade de relatar seu sofrimento relativo aos abusos que sofreram e recomendando medidas de reparação. O pressuposto de que as vítimas e suas famílias precisam de atenção e respeito é a base para a justiça restaurativa.

Muitos sobreviventes têm atestado o poder curativo de prestar depoimento perante um oficial da Comissão de Verdade depois de uma vida inteira sendo ignorados, desrespeitados e oprimidos por agentes do Estado. Um homem sul-africano respondeu a um oficial da Comissão de Verdade, quando perguntado o que sentia depois de prestado o testemunho: "Eu sinto que o que me deixava doente era o fato de não poder contar minha história. Mas agora... é como se eu recuperasse minha visão vindo aqui” (KISS, 2000, p. 72, tradução minha). Segundo o relatório final da Comissão, os testemunhos das vítimas não são tratados como alegações em uma corte judicial, mas como uma verdade pessoal que fornece uma idéia única da dor que a África do Sul suportou. As audiências também visam entender os motivos e as perspectivas das pessoas responsáveis pelas violações aos direitos humanos. Assim, o processo é dialógico, buscando restaurar a dignidade de ambos os lados.

A abordagem restaurativa confronta e desaprova as transgressões, afirmando o valor intrínseco da pessoa do transgressor. A essência da justiça restaurativa é a resolução de problemas de forma colaborativa. Práticas restaurativas proporcionam, àqueles que foram prejudicados por um incidente, a oportunidade de reunião para expressar seus sentimentos, descrever como foram afetados e desenvolver um plano para reparar os danos ou evitar que aconteça de novo. A abor- 


\section{Simone Martins Rodrigues Pinto}

dagem restaurativa é reintegradora e permite que o transgressor repare danos e não seja mais visto como tal.

A presença do arcebispo em um órgão quase judicial não foi à toa. Embora a Comissão tivesse vários advogados e juristas, a presença do arcebispo Tutu garantia uma atmosfera de confiança e conforto. $\mathrm{O}$ discurso religioso é mais afeito à ênfase no perdão, na reconciliação e na reabilitação, conceitos estranhos ao discurso político e jurídico. As vítimas e testemunhas eram acompanhadas por pessoas que sentavam ao seu lado enquanto elas testemunhavam. Água e lenços eram fornecidos quando necessário. Tudo para criar um ambiente amistoso e confortável. Tentava-se tirar a impressão de que os depoentes estavam sentados em um banco dos réus e, por isso, ficavam sentados no mesmo nível dos comissionados.

Em um sistema violento e opressivo, a mensagem que é passada às vítimas é a de que são pessoas marginais ou irrelevantes. A auto-estima e respeito próprio, ou seja, a própria identidade é afetada e precisa ser reconstruída. Justiça restaurativa, em resposta a um legado de opressão e violência, significa restaurar a dignidade e dar voz às vítimas de injustiça, responsabilizar os agentes da injustiça e dar condições para que todos sejam tratados com respeito. Ao privilegiar a reconciliação e a reparação a despeito da punição, a justiça restaurativa requer uma parcela de fé na possibilidade de transformação moral das pessoas e das instituições. Como Arendt (1997) nos lembra, punição e perdão são caminhos alternativos à vingança e de busca de construção de uma ordem moral legítima. O problema dos conflitos vai além de uma ordem legal, mas passa pela ordem moral. Em alguns casos, como na África do Sul, a ordem legal era bem estabelecida, mas, como no Terceiro Reich, por exemplo, era moralmente reprovável. Portanto, tanto a justiça retributiva quanto a restaurativa têm seu papel definido na reconstrução moral da sociedade, mas a restaurativa é mais ambiciosa nos seus objetivos. Extrapola os limites da mera resposta aos interesses e direitos das vítimas e procura 
atingir, de forma mais eficaz, o nível da reprovação moral e da restauração da dignidade.

\section{Perspectivas da Transição}

O exemplo dado pela África do Sul é o de que as sociedades devem se prevenir da recorrência das atrocidades passadas afastando-se do efeito corrosivo da mágoa e da vingança. As Comissões de Verdade surgem como uma tentativa de revelar os fatos e de tratar, em um nível mais profundo, a ferida social em sociedades que emergem de governos totalitários ou de guerras que deixam um rastro de opressão e mentira.

As primeiras comissões - Uganda, Bolívia, Argentina, Zimbábue, Uruguai, Filipinas, Chile e outras - não ouviram os testemunhos em público por medo de represálias e, neste sentido, a Comissão de Verdade e Reconciliação da África do Sul serve como exemplo principal de publicidade e transparência. Em um país em que o terror se tornou um dos principais instrumentos do controle estatal sobre os negros, mestiços e indianos, baseado em uma propaganda pesada e enganosa que mostrava os não-brancos como bárbaros, violentos e inferiores, a construção da verdade surge como principal aliada na reconstrução nacional.

A história do passado não é apenas uma. Surgem várias vozes para explicar o que ocorreu. A verdade vai surgir à medida que essas vozes forem ouvidas e se puder construir um amplo espectro de versões que vão dando forma aos fatos. É a construção não só da verdade, mas também da memória coletiva, que pode servir para aguçar ou acalmar animosidades entre as diversas facções sociais. A reprovação moral de toda a sociedade é o primeiro passo para o recomeço.

Uma novidade no relatório da Comissão de Verdade e Reconciliação da África do Sul é a afirmação de que a linguagem ideológica é um 


\section{Simone Martins Rodrigues Pinto}

dos principais fatores que contribuíram para as violações dos direitos humanos. Baseado no construtivismo social, o argumento é de que a linguagem "faz" coisas como dar ordens, criar conspirações, construir inimigos e motivar pessoas a agir. Dessa forma, uma nova linguagem tem de ser estabelecida como instrumento de paz e unidade no país.

As comissões de verdade são um novo instrumento capaz de fortalecer a sociedade civil e promover uma justiça restaurativa porque elas têm um papel investigativo, judicial, político, educativo e terapêutico, simultaneamente. Elas podem alcançar ambições morais, de restauração de valores em uma sociedade em transição, influenciando a reconstrução sadia da identidade nacional. No centro desta inovação, está uma justiça centrada na vítima e não no réu. A meta é reorientar uma sociedade que perdeu seu parâmetro moral, que não é recuperado apenas com julgamentos criminais ou leis de purificação. O ponto principal é ajudar a comunidade a criar uma história compartilhada como base para a cooperação política futura.

Embora em muitos países já se houvesse experimentado Comissões de Verdade, a da África do Sul foi única em sua contingência moral, legal e social. Seu mandato era bem abrangente e ambicioso. O confronto com o passado foi largamente noticiado pela mídia e as audiências públicas foram acompanhadas em todo o país. Ninguém vítimas, violadores ou os omissos $-{ }^{8}$ deixou de ser envolvido. A Comissão de Verdade encorajou todos os sul-africanos a refletirem sobre os abusos que cometeram, ainda que estivessem fora da jurisdição da Comissão, que trata somente das graves violações aos direitos humanos como assassinatos, estupros e tortura. ${ }^{9}$ A Comissão criou ainda um órgão próprio para receber reflexões pessoais de quem desejasse enviar declarações reconhecendo sua responsabilidade direta ou indireta pela opressão do apartheid. 
Em sociedades devastadas pela violência e pela divisão hostil entre classes ou etnias, a comissão de verdade opera como a opção mais eficiente para a reconciliação e cura dos traumas individuais e coletivos. Na África do Sul, a Comissão de Verdade e Reconciliação não substituiu os julgamentos criminais. Houve muitos julgamentos paralelos. Mas a contribuição para a restauração da dignidade nacional e para a reprovação moral da segregação deu-se principalmente por meio das audiências conduzidas pela Comissão.

Como transformar uma sociedade econômica e politicamente baseada na raça, separação tradicionalmente construída ao longo de décadas, em uma sociedade baseada em padrões não raciais e não sexistas? Uma mudança estrutural deste calibre deve ser baseada em uma perspectiva moral de construção de uma nova legitimidade, de novos valores. Esta construção de novos valores e normas esbarra em interesses há muito estabelecidos. Toda a economia da África do Sul estava fundada no apartheid. A indústria da exploração mineral e a agricultura sustentaram-se na exploração da mão-de-obra negra, em um sistema trabalhista repressivo. $\mathrm{O}$ acesso privilegiado a terras também garantia aos brancos a primazia econômica. Reverter esta situação não é simples, mas possível. Medidas compensatórias e ações afirmativas são políticas necessárias para desmantelar um sistema que, ainda que não mais baseado na diferença racial, continua firmado no abismo econômico.

Muitos ativistas de direitos humanos e acadêmicos defendem que a melhor resposta às atrocidades é o julgamento criminal. No entanto, em regimes criminosos, em que é impossível separar vítimas de violadores, sendo difícil distinguir crime de sistema criminoso, as comissões de verdade surgem como a alternativa mais apropriada para apurar os fatos, uma vez que permitem um amplo espectro de declarações, oitivas e testemunhos. Fica mais claro o papel do sistema na medida em que são valorizadas as perspectivas de todas as partes envolvidas. O apartheid é um sistema de engenharia social e política 
que atinge todas as áreas da vida, do nascimento à morte - define questões de terra, moradia, educação, transporte, saúde, esportes, alimentação e enterro. Avaliar seu papel na configuração das relações sociais do país requer muito mais do que um julgamento formal e limitado de avaliação de culpa e punição.

O testemunho das vítimas levou muitos brancos a reconhecerem sua responsabilidade, ainda que por omissão, e a converterem seus valores e modos de pensar. Esses depoimentos forneceram muito mais do que fatos objetivos ou informações frias. Forneceram a base para uma nova sociedade cujo lema principal é nunca mais!

\section{Notas}

1. Os colonos holandeses eram chamados de "bôeres" pelos britânicos, mas se autodenominavam africânderes, desenvolvendo sua própria língua - $\mathrm{o}$ africânder.

2. Sobre as guerras bôeres, ver Pakenham (1992, p. 40-71).

3. Para mais informações, ver: <http://www.anc.org.za/>.

4. Mbeki tornou-se presidente da África do Sul nas eleições de 1999.

5. Esta citação, assim como as demais citações escritas originalmente em língua estrangeira, foram traduzidas livremente para este artigo.

6. Dois de seus três membros eram integrantes do CNA.

7. O personagem principal de Victor Hugo, Jean Valjean, depois de passar alguns anos na prisão por ser pego furtando pão, passa dias procurando onde ficar, antes de ser recebido por um bispo em sua casa. Valjean aproveita a oportunidade para lhe furtar as pratarias e fugir. Pego por alguns soldados, que o levam ao encontro do bispo, Valjean é surpreendido pela reação de graça e perdão do bispo, que afirma aos policiais que havia pessoalmente presenteado o ladrão com 
tais pratarias. Esta atitude do bispo provoca um processo de restauração e reintegração social do miserável personagem (HUGO, 2001).

8. Chamados de bystanders.

9. A Comissão de Verdade e Reconciliação é limitada aos casos de grave violação aos direitos humanos, o que exclui outros casos como as mais de 3,5 milhões de pessoas que foram forçadamente realocadas entre 1960 e 1982.

\section{Referências Bibliográficas}

ARENDT, Hannah. A condição humana. 8. ed. Rio de Janeiro: Forense Universitária, 1997.

BOBBIO, Norberto; MATTEUCCI, Nicola; PASQUINO, Gianfranco. Dicionário de política. 8. ed. Brasília: Editora UnB, 1985. 2 vol.

BORAINE, Alex. Truth and reconciliation in South Africa: the third way. In: ROTBERG, R.; THOMPSON, D. Truth vs. justice: the morality of truth commissions. New Jersey: Princeton University Press, 2000.

HAYNER, Priscilla. Unspeakable truths: confronting state terror and atrocities. London: Routledge, 2002.

HUGO, Victor. Les misérables. Paris: Larousse, 2001.

JONGE, Klaas de. África do Sul, apartheid e resistência. São Paulo: Editora Cortez, 1991.

KISS, Elizabeth. Moral ambition within and beyond political constraints: reflections on restorative justice. In: ROTBERG, R.; THOMPSON, D. Truth vs. justice: the morality of truth commissions. New Jersey: Princeton University Press, 2000.

MINOW, Marta. Between vengeance and forgiveness. Boston: Beacon Press, 1998.

PAKENHAM, Thomas. The scramble for Africa: white man's conquest of the dark continent from 1876 to 1912. New York: Avon Books, 1992. 
SELETI, Yonah. South Africa today: prospect for a non-racist democratic society. In: GRIFFITHS, A. L. Building peace and democracy in post-conflict societies. Halifax: Dalhousie University, 1998.

TUTU, Desmond. No future without forgiveness. New York: First Image Press, 2000.

VILLA-VICENCIO, Charles; VERWOERD, Wilhelm. Looking back reaching forward: reflections on the Truth and Reconciliation Commission of South Africa. Cape Town: University of Cape Town Press, 2000.

\section{Resumo}

\section{Justiça Transicional na África do Sul: Restaurando o Passado, Construindo o Futuro}

A transição democrática na África do Sul foi dolorosa, mas pacífica. Após anos de opressão estatal violenta em uma sociedade marcadamente dividida entre brancos e negros, o processo transicional permitiu o surgimento de uma sociedade democrática, caminhando para a restauração psicológica e reconciliação social. Um dos fatores principais para o êxito deste processo foi o fato de se ter optado pela justiça restaurativa como meio de resolver os crimes cometidos pelo regime passado. Por meio de uma Comissão de Verdade e Reconciliação, a África do Sul abre mão de um modelo punitivo tradicional sem deixar de lado a responsabilização dos criminosos e a apuração da verdade.

Palavras-chave: África do Sul - Justiça Transicional - Apartheid - Comissão de Verdade - Democracia 


\section{Abstract}

\section{Transitional Justice in South \\ Africa: Restoring the Past, Rebuilding the Future}

The democratic transition in South Africa was painful but peaceful. After years of state violent oppression in a society remarkably divided between blacks and whites, the transitional process allowed the emergence of a democratic society, walking to psychological restoration and social reconciliation. One of the most important elements to the success of this process was the option for restorative justice as a way to solve crimes committed during the past regime. Because of the Truth and Reconciliation Commission, South Africa refused a punitive model but guaranteed criminal responsibility and investigation of the facts.

Keywords: South Africa - Transitional Justice - Apartheid - Truth Comission - Democracy 